\section{大型火力発電所で観測された鳥 取県西部地震および芸予地震の 記録とそのシミュレーション解 析}

\title{
SIMULATION ANALYSIS OF EARTHQUAKE RECORDS OBSERVED AT A LARGE-SCALE THERMAL POWER STATION IN THE TOTTORIKEN-SEIBU AND GEIYO EARTHQUAKES
}

\section{宮川信幸 一 $* 1$ \\ 宮村正光 一 $* 2$ \\ 武井邦生 一 $* 3$ 杉本 - - $* 4$}

キーワード

火力発電所, 鳥取県西部地震, 芸予地震, 観測記録, シミュレーション解析, 非線形特性，サイスミックタイ

Keywords :

Thermal power station, Tottoriken-Seibu and Geiyo earthquake, Observed records, Simulation analysis, Nonlinear property, Seismic tie
Nobuyuki MIYAGAWA - $* 1$

Kunio TAKEI

Masamitsu MIYAMURA —*2

Hajime SUGIMOTO $-* 4$

Earthquake observation system installed at the Takehara Thermal Power Station has been operated since 1983 and many earthquake records have been observed and accumulated. During this period, two large earthquake records were observed in the Tottoriken-Seibu and Geiyo earthquakes. In this paper, the simulation analysis was performed focusing on the nonlinear property of seismic tie connecting building and boiler based on the information obtained by observed data. The vibration model and evaluated major input parameters can well simulate the general feature of response properties of building and boiler both in two earthquakes and verify the vibration model used for the design of this building.

\section{1. はじめに}

広島県竹原市に建設された竹原火力発電所 3 号機ボイラ建屋では、 1983 年の竣工以来現在にいたるまで 20 年余りにわたり地震観 測が継続されている。この間、多くの中小地震の記録が観測、蓄積 されてきたが、 2000 年 10 月の鳥取県西部地震と翌年 3 月の芸 予地震と相次いで、観測期間中の最大規模の地震が観測された。現 在までこのような大型の火力発電所ボイラー建屋で観測された大き な地震記録は少なく、建物設計時に用いた解析モデルの妥当性を検 証する上で、貴重なデータが得られた。

本建屋の構造上の特徴として、事務所ビルなど一般の建築物とは 異なり、大型の柱、梁、鉄骨ブレースにより立体架構が構成され、 建物内部には全重量 $44000 \mathrm{t}$ の約 4 分の 1 に相当する重さのボイラ 一が頂部より吊り下げられる構造形式であること、ボイラーと建屋 の間はサイスミックタイと呼ばれる鋼製ダンパーで連結され、この 特性が建屋全体の振動挙動に大きな影響を与えていることがあげら れる。

本報告ではこれらの記録を分析し、2つの地震における建屋、ボ イラーの特徴的な振動挙動を把握すると共に、設計時の解析モテル を用いて、サイスミックタイの非線形特性を考慮して、建屋全体の 応答性状とボイラーと建屋間の振動挙動に着目したシミュレーショ ン解析を行った。

\section{2. 地震の概要}

観測された地震の概要は表 1 のとおりで、 20 年間の観測期間中 最大級の地震動強さである。鳥取県西部地震は M7.3、震源距離 $120 \mathrm{~km}$ の比較的遠距離の地震であるのに対し、芸予地震は M6.4, 震源距離 $45 \mathrm{~km}$ の近距離地震である。震源位置と建物位置を図 1 に 示す。

\begin{tabular}{|c|c|c|c|c|c|c|}
\hline 地震名称 & $\begin{array}{l}\text { 地震発生 } \\
\text { 日時 }\end{array}$ & 震源 & 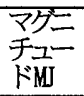 & $\begin{array}{c}\text { 震央 } \\
\text { 距 } \\
(\mathrm{km})\end{array}$ & $\begin{array}{l}\text { 震源 } \\
\text { 梁さ } \\
(\mathrm{km})\end{array}$ & 震度 \\
\hline $\begin{array}{l}\text { 鳥取県 } \\
\text { 西部地震 }\end{array}$ & $\begin{array}{l}2000.10 .06 \\
13 \text { 時30分 }\end{array}$ & 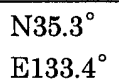 & 7.3 & 115 & 15 & 4 \\
\hline 芸予地震 & $\begin{array}{l}2001.03 .24 \\
15 \text { 時28分 }\end{array}$ & $\begin{array}{l}\text { N34. } 1^{\circ} \\
\text { E132. }\end{array}$ & 6.4 & 35 & 51 & 5 \\
\hline
\end{tabular}

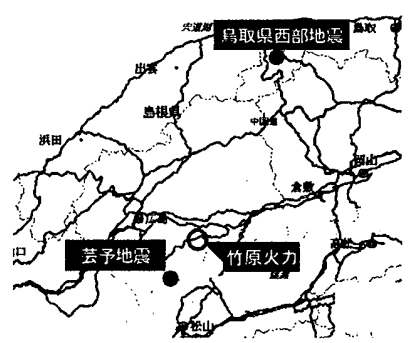

図 1 震源位置と建物位置

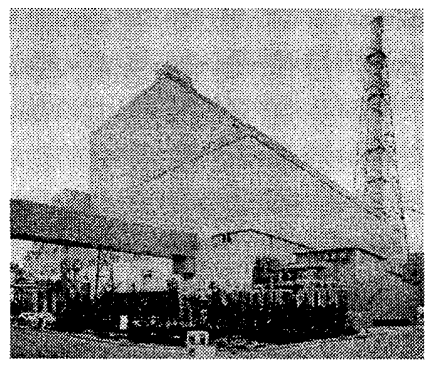

写真 1 建物外観

\footnotetext{
*1 侏小堀鐸二研究所構造部 部長 （广107-8502 東京都港区赤坂6-5-30）

*2 (侏小堀鐸二研究所研究部 部長・工博

*3 電源開発(侏エンジニアリング事業部建築施設事業グループ 課長代理

*4 (侏開発設計コンサルタント建築事業部 建築設計部長
}

*1 Manager, Kobori Research Complex Inc., Structural Department

*2 Manager, Kobori Research Complex Inc., Research Department, Dr. Eng.

*3 Assistant Manager, Electric Power Development Co., Ltd, Architecture Group, Engineering Department

*4 Manager, Development Design Consulting Co., Ltd., Architectural Department 


\section{3. 建物と地震記録の概要}

3. 1 建物概要、地震計の設置位置とサイスミックタイの形状

観測対象の竹原火力発電所 3 号機ボイラ建屋は広島県竹原市にあ る出力 70 万 $\mathrm{KW}$ の石炭火力発電所である。建屋の平面形状は $87 \mathrm{~m} \times$ $63 \mathrm{~m}$ の矩形で、高さは $77.1 \mathrm{~m}$ である。橉接するタービン建屋とは構 造上分離している。建屋の主要構造は鉄骨造でブレース構造であり、 内部には約 $12000 \mathrm{t}$ のボイラ函体が頂部大梁から吊り下げられてい る。ボイラと建屋はサイスミックタイ(鋼製)により数十点で連結さ れ、これにより地震時の振動が抑えられている。基礎版は径 $1.5 \mathrm{~m}$ のベノト杭により風化花崗岩層に支持されている。建屋の平面図お よび断面図を図 2 、図 3 に示す。
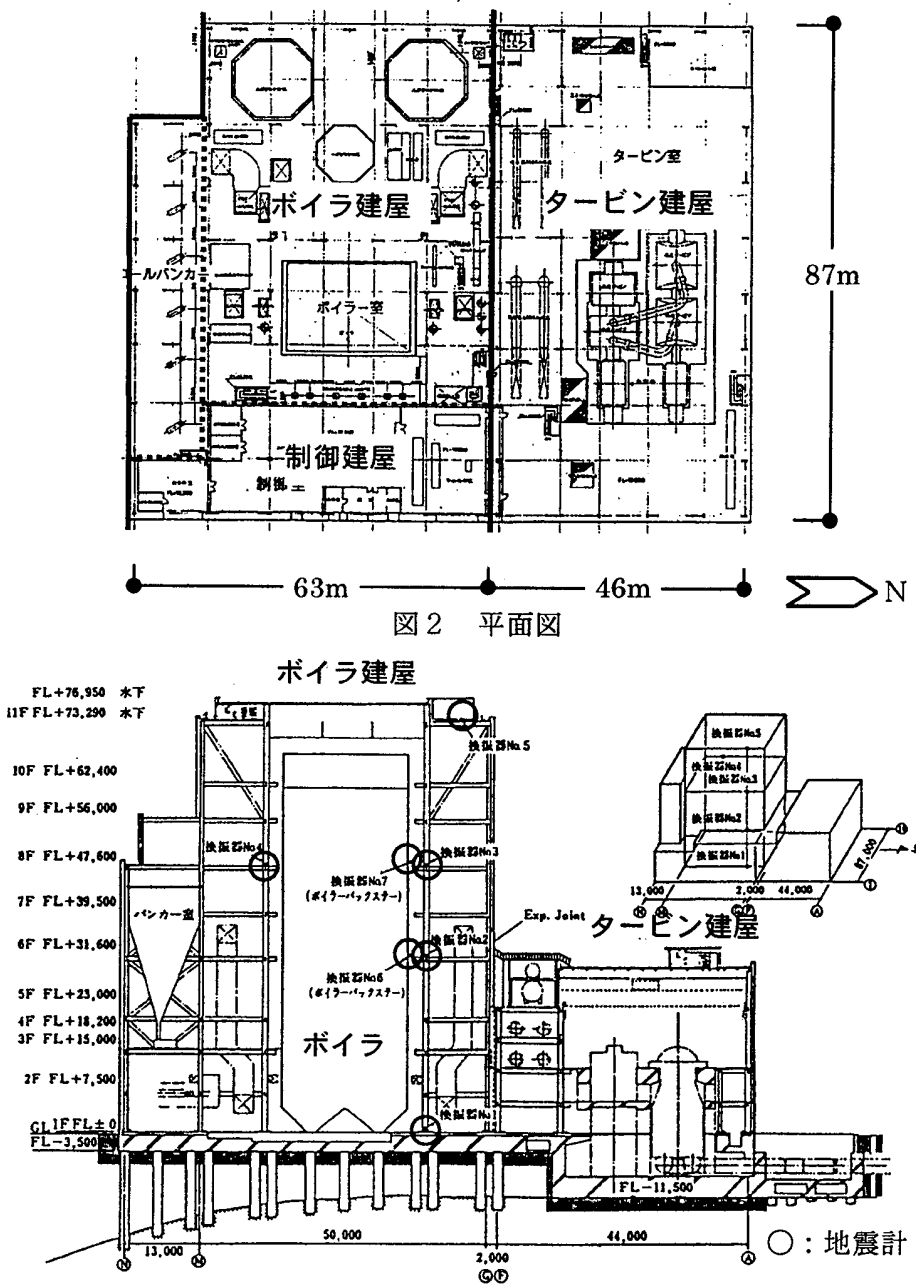

図 3 建物 N S 方向断面図と地震計設置位置

地震観測には 3 成分のサーボ型加速度計を用いており、その設置 位置は建屋側 5 点 $(1$ 階東側 $(F L+0.0 \mathrm{~m}) 、 6$ 階東側 $(F L+31.6 \mathrm{~m}) 、 8$ 階 東側 $(F L+47.6 \mathrm{~m}) 、 8$ 階西側 $(F L+47.6 \mathrm{~m}) 、 11$ 階東側 $(\mathrm{FL}+73.3 \mathrm{~m}))$ 、ボ イラ側 2 点 (6 階東側 $(F L+31.6 \mathrm{~m}) 、 8$ 階東側 $(F L+47.6 \mathrm{~m})$ ) の計 7 点 21 チャンネルである。図 3 中に地震計設置位置を示す。

サイスミックタイには図 4 に示す 2 つのタイプがあり、4 階〜11 階までの各階に設置されている。NS 方向はリンク式が 10 か所、挟 込夕式が 14 か所の合計 24 か所であり、EW 方向はリンク式が 18 か 所である。サイスミックタイは熱膨張による変形を吸収するために 建屋とボイラとの間に数 $\mathrm{mm}$ のギャップ (隙間間隔)を保つ機構であ り、その設計值はリンク式では $9 \mathrm{~mm}$ 、挟込み式では $2.3 \sim 4 \mathrm{~mm}$ である。

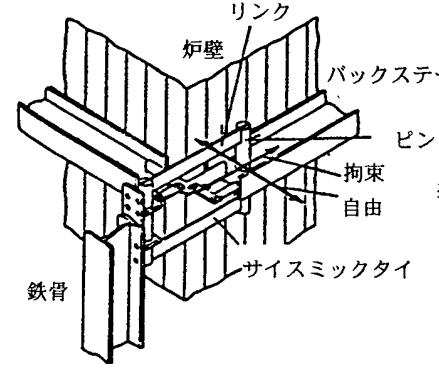

(リンク式)

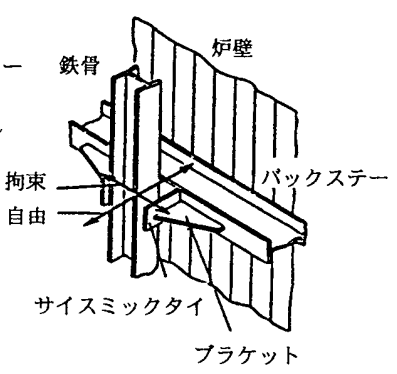

（挟込み式）
図 4 サイスミックタイの形状

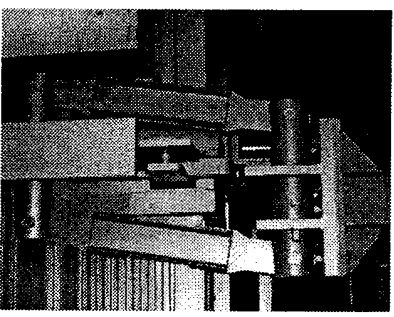

リンク式

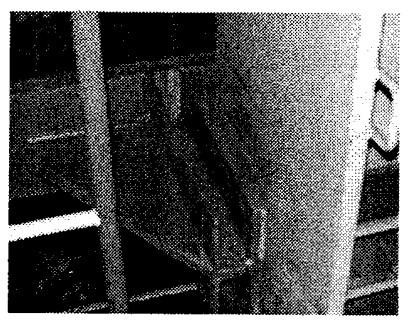

挟込夕式
写真 2 サイスミックタイの外観

\section{2 観測記録の分析}

\section{（1）加速度最大値分布と加速度波形}

観測された各点の加速度最大值を表 2 に、加速度波形 (N S 方向) を図 6 に示す。 2 つの地震における建屋の水平方向最大加速度は 1 階床で $35 \sim 50 \mathrm{~cm} / \mathrm{s}^{2}$ 、頂部で $80 \sim 170 \mathrm{~cm} / \mathrm{s}^{2}$ 程度である。1 階床に対 する建屋頂部の応答倍率は図 5 に示すように水平、上下共 2 倍 3.5 倍である。いずれの地震においても地震後の調查では建屋の主要構 造部、ボイラおよびサイスミックタイ周辺に損傷は見られなかった。 6 階と 8 階には建屋、ボイラの両方に地震計が設置してあり、両者 の挙動の比較が可能である。2 地震の振動性状を見ると、8階位置 では建屋、ボイラはほぼ同じ動きをしているのに対し、6階ではボ イラ側に建屋との接触によると見られる大きな加速度が生じている。 表 2 加速度最大值 $\left(\mathrm{cm} / \mathrm{s}^{2}\right)$

\begin{tabular}{|c|c|c|c|c|c|c|c|c|}
\hline 地 & \multirow{2}{*}{ 霞 } & 階 & 高さ & \multicolumn{2}{|c|}{ NS } & \multicolumn{2}{|c|}{ EW } & \multicolumn{2}{|c|}{ ( } \\
\cline { 3 - 10 }
\end{tabular}

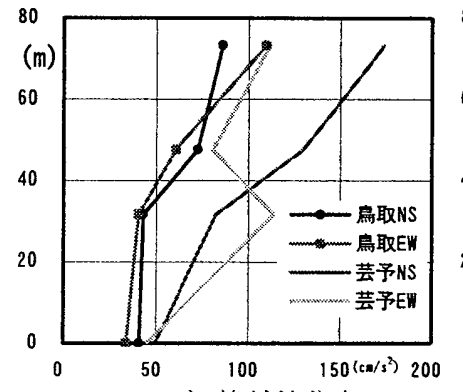

a）絶対値分布

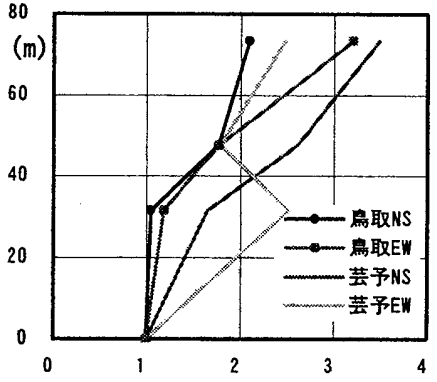

b ）店答倍率
図 5 水平最大加速度分布 


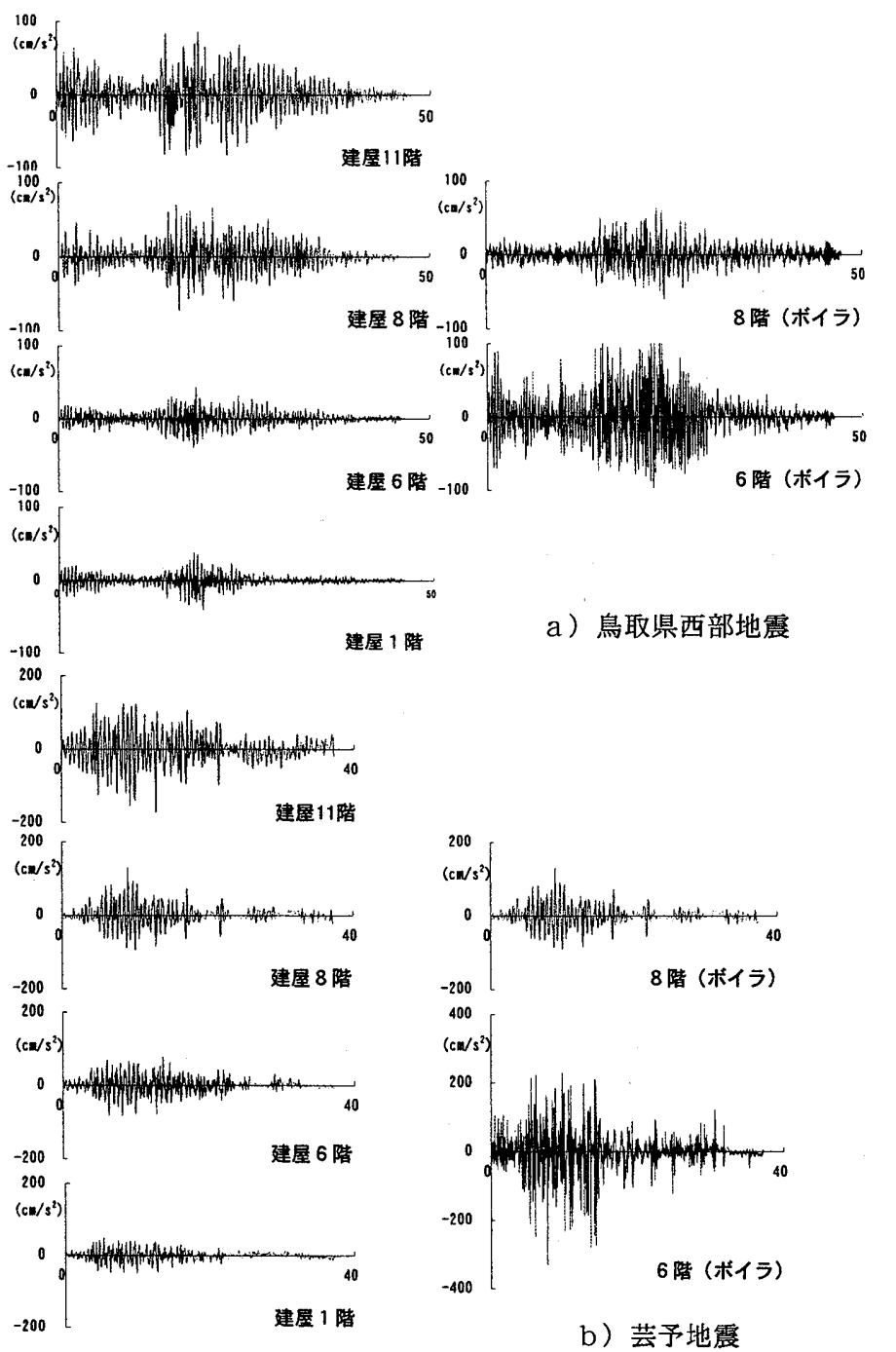

図6 加速度波形（NS 方向）

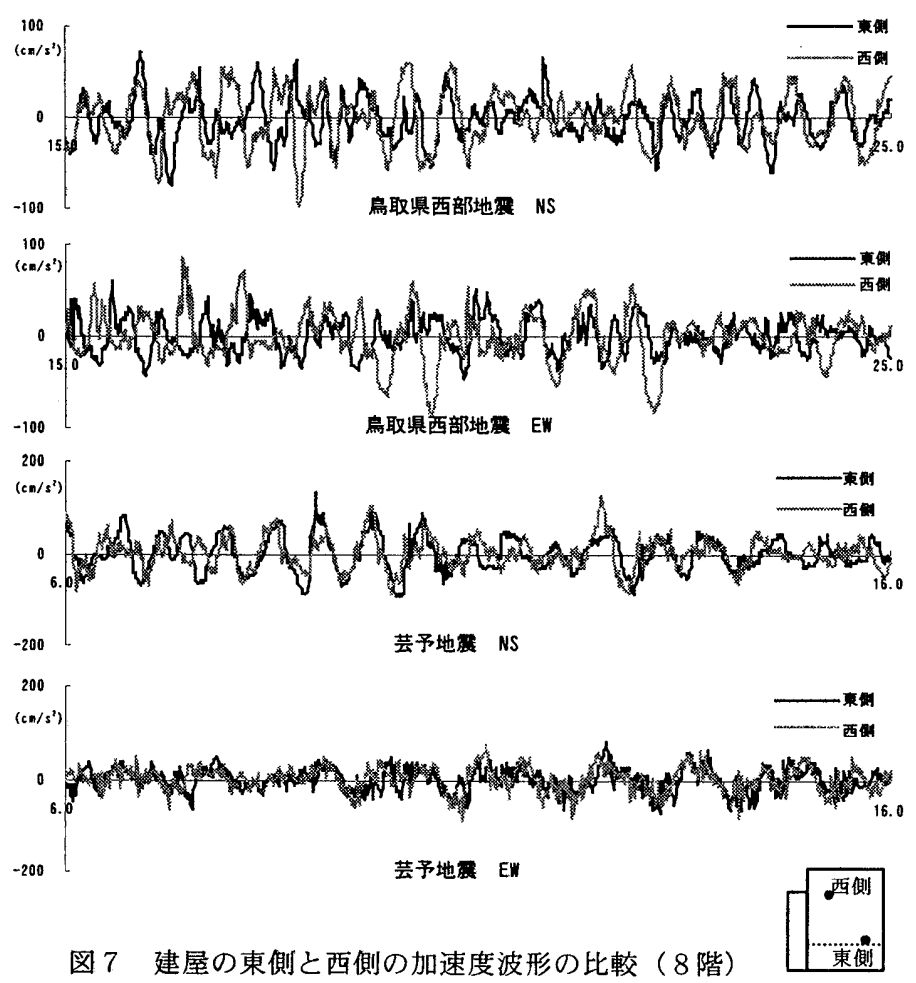

\section{（2）ねじれの影響}

8 階に設置された同一平面内の 2 つの地震計から得られた観測記 録の主要動付近を拡大して図 7 に示す。鳥取県西部地震では振幅の 大きい部分で若干位相ずれが生じており、ねじれの影響が見られる。 芸予地震ではN S 方向EW方向共ほぼ同位相で振動しており、ねじ れの度合いは小さい。

\section{(3) 周波数分布}

観測記録の加速度応答スペクトルと伝達関数（フーリエスペクト ルの 11 階 $/ 1$ 階の比）とを図 8 、図 9 に示す。伝達関数にはハミン グウィンドウを施し、平滑化を行っている。

これらのスペクトルを見ると、振動特性が地震ごとに変動してお り、建屋とボイラの接触の影響も含まれると思われるが、建屋の卓 越周期と見られる 0.6 秒付近に共通してピークが見られる。芸予地 震ではこのピークに加え、入力波に見られる1秒付近のピークが建 屋各階にも現れ、鳥取県西部地震とは異なる性状を示している。

鳥取県西部地震の加速度波形は、10 秒前後を境に前半と後半に 2 山の包絡形状を示しているが、この部分の卓越周波数成分の時間的 変動を調べるため、ランニング応答スペクトルを計算して図 10 に
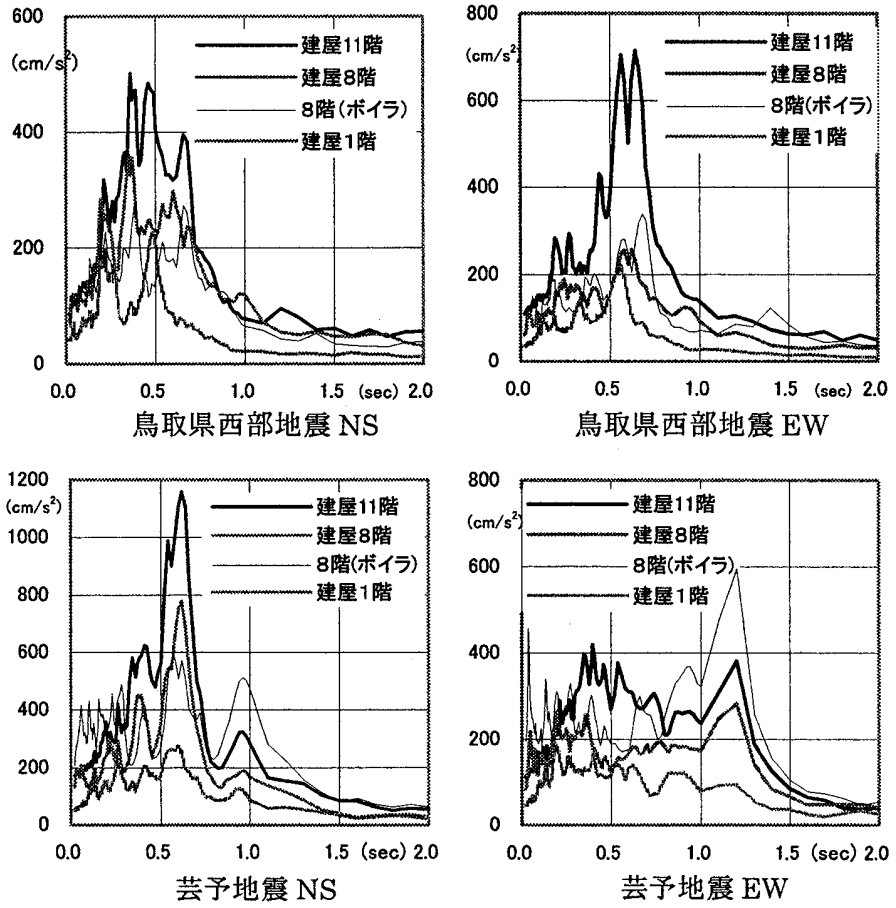

図 8 加速度応答スペクトル $(\mathrm{h}=0.03)$
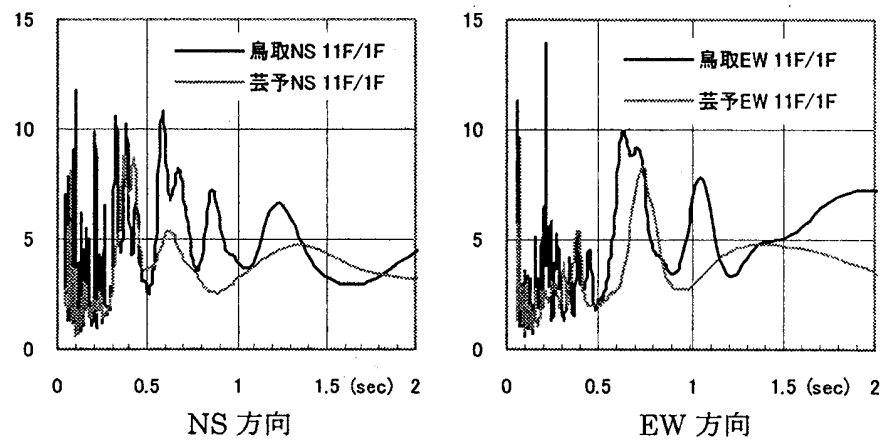

図 9 伝達関数 $(11 \mathrm{~F} / 1 \mathrm{~F})$ 
示した。図 10 は綐軸に固有周期を取り、横軸に継続時間を取って 応答値を濃淡で示したものである。スペクトルのピーク位置の時間 経過に伴う変動は小さく、入力波、建屋頂部共に周波数成分の非定 常性は見られない。

\section{周期 $(\mathrm{sec}$ )}
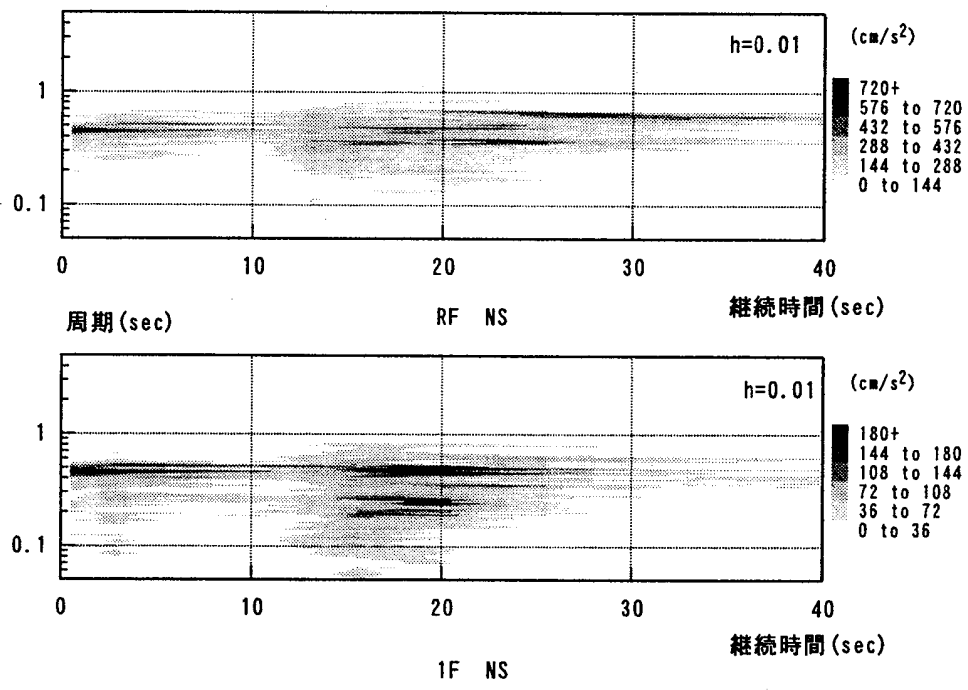

図 10 加速度ランニング応答スペクトル（鳥取県西部地震）

（4）建屋ボイラ間の相対変位

観測記録を文献 3）の方法により数值積分して得られた変位波形 （計器特性を考慮して 5.0 秒以上の長周期成分をカットしている。） から求めた建屋ボイラ間の相対変形の最大値を表 3 に示す。これら はサイスミックタイのギャップ間隔の設計值を越えており、ほとん どの場所で建屋とボイラは接触している状況と見られる。

表 3 建屋ボイラ間の相対変位

\begin{tabular}{|c|l|c|c|}
\hline \multirow{2}{*}{ N S } & & 8 階 $(\mathrm{cm})$ & 6 階 $(\mathrm{cm})$ \\
\cline { 2 - 4 } & 鳥取県西部地震 & 0.9 & 0.9 \\
\cline { 2 - 4 } & 芸予地震 & 1.7 & 2.0 \\
\hline \multirow{2}{*}{ E W } & 鳥取県西部地震 & 1.4 & 0.8 \\
\cline { 2 - 4 } & 芸予地震 & 1.7 & 1.7 \\
\hline
\end{tabular}

4. シミュレーション解析

\section{(1) 解析モデル}

解析モデルは柱、梁、ブレースを部材ごとにモデル化し、各フレ 一ム間を等価なせん断ばねでつなぐことによりねじれ性状を表現し た擬似立体精算モデルである。ボイラは質点系の曲げせん断型でモ デル化している。柱・梁・ブレース材は弾性とし、サイスミックタ イにのみ非線形特性を考慮して図 12 に示すようなギャップを持つ 非線形ばねでモデル化する。地震計が 1 階床位置に設置してあるの で、水平は地盤との相互作用を含んだものと考え、さらに杭を評価 した回転ばねは十分大きく固有値に影響がないことを予備解析モデ ルで確認した上で、基礎はモデル化せず 1 階床を固定とした。振動 解析モデルを図 11 に示す。建屋ボイラ非連成時の固有周期は表 4 のとおりであり、観測記録の卓越周期に比べやや長周期側の值とな っている。建屋モデルの特性に影響を及ぼす要因としては、ボイラ 重量の変動や 2 次部材の影響などが考えられるが、建屋・ボイラの 重量と剛性は設計值どおりの値を用い、特に修正は行っていない。
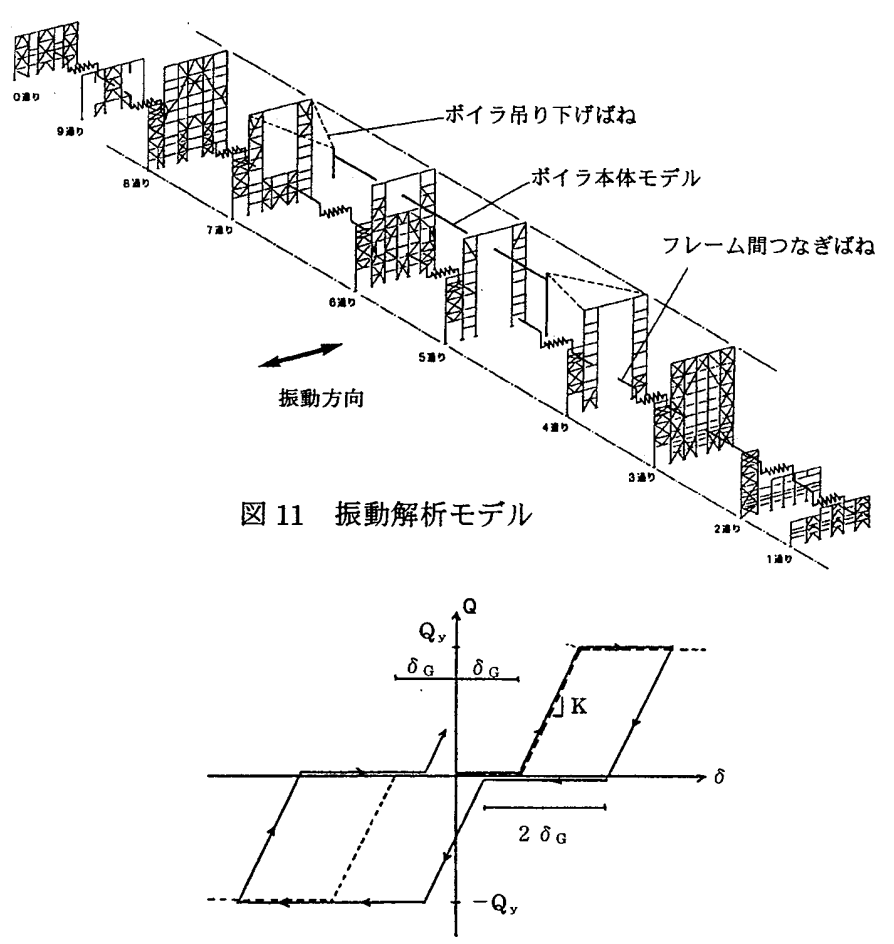

図 12 サイスミックタイの履歴特性

表 4 解析モデルの固有周期（sec）（建屋ボイラ非連成時）

\begin{tabular}{|c|c|c|c|}
\hline & 1 次 & 2 次 & 3 次 \\
\hline N S & 0.74 & 0.39 & 0.30 \\
\hline EW & 0.73 & 0.46 & 0.31 \\
\hline
\end{tabular}

（2）シミュレーション解析のプロセス

シミュレーション解析においては図 13 に示すフローチャートに 従って予備解析を絽返し、応答スペクトルと時刻歴波形の対応の良 い条件を求め次のとおりとした。主要なパラメータはサイスミック タイの減衰定数・剛性・ギャップ間隔、建屋の減衰定数である。

サイスミックタイの減衰定数は建屋とサイスミックタイの接触状 況によらずゼロと仮定した。サイスミックタイのギャップ間隔の設 定は建屋とボイラの接触の程度を支配し建物の応答值に影響を及ぼ すため、N S 方向は設計值を用いたが $\mathrm{EW}$ 方向は一律 $0.4 \mathrm{~cm}$ とした。 設定に際しては現地調查を行い、ギャップ間隔が施工精度から見て 設計值から $0.2 \sim 0.5 \mathrm{~cm}$ 程度の範囲で変動し得ることを確認してい る。建屋の減衰定数は建屋ボイラ非連成時の 1 次固有周期に対する 值として設計值の $3 \%$ $\%$ やや大きめではあるが、 $5 \%$ 内部粘性型 とした場合が記録との対応が最も良好であり、この值を用いた。本 建物の場合、建屋・ボイラの連成による減衰効果が期待できること がうかがわれる。

\section{（3）解析結果}

解析結果と観測記録との加速度応答スペクトルの比較を図 14 に示す。鳥取県西部地震においてはサイスミックタイのない線形解 析の結果を合せて示した。解析結果と観測記録では 0.6 秒付近と見 られる卓越周期はほぼ対応している。芸予地震に見られる周期 1 秒 付近の卓越振動（NS0.9 秒、EW1.2 秒）は解析結果にも見られるが、 この振動モードは解析モデルにはなく、入力波の特性がそのまま建 


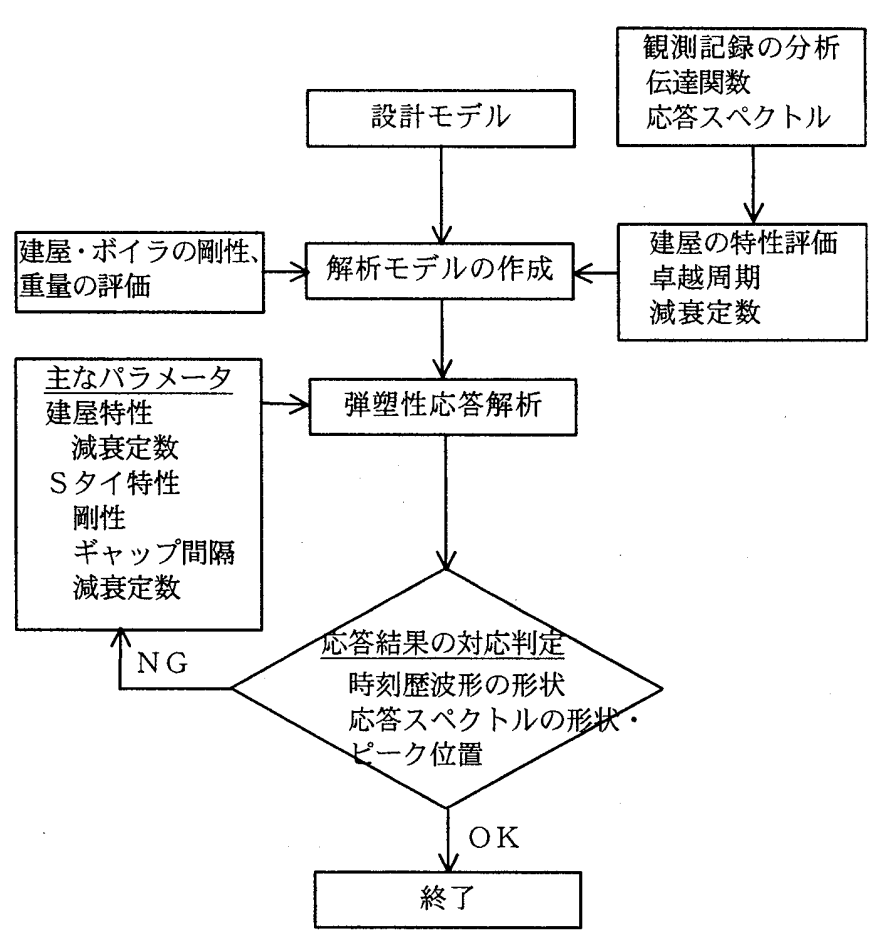

図 13 シミュレーション解析のフローチャート
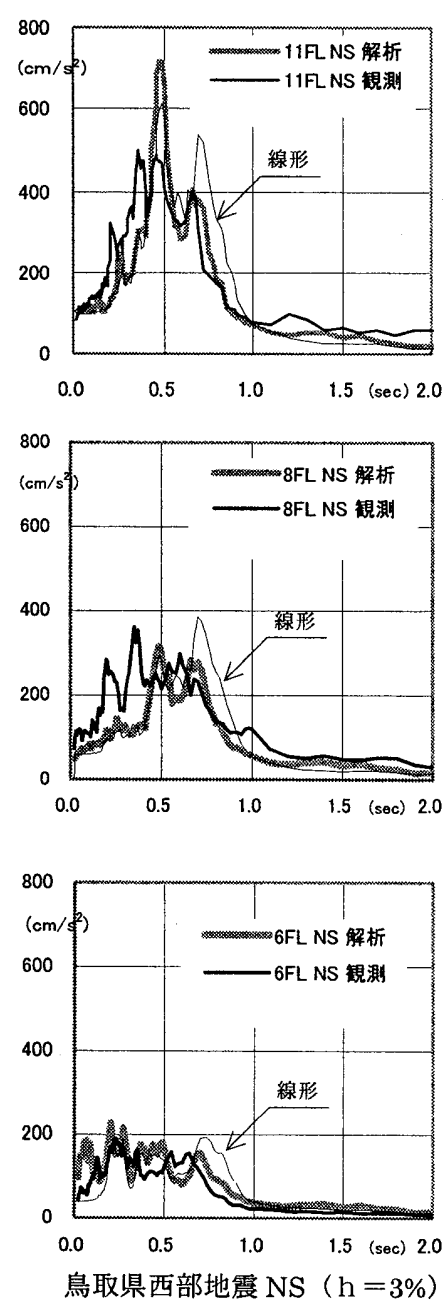
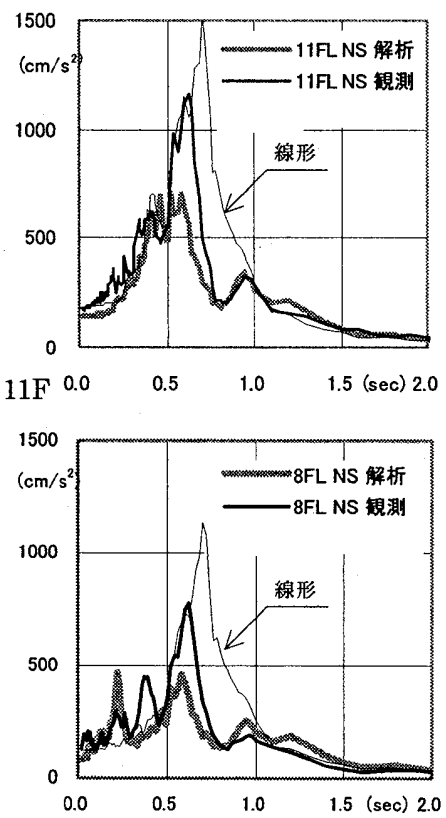

$8 \mathrm{~F}$

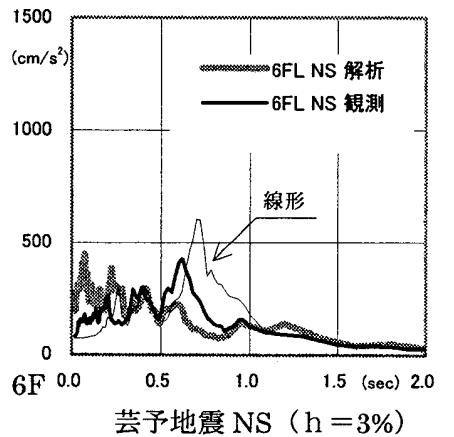

屋に表れたものと考えられる。スペクトルピーク值は鳥取県西部地 震では 2 方向共に良い対応を示すが、芸予地震ではややばらつきが 見られ、EW方向 11 階の解析結果が観測記録に比べて大きめの結果 となっている。しかし全体的には解析結果は観測記録のスペクトル 性状を良く表現している。ここではサイスミックタイのギャップ間 隔は細かな変更はせず一律の值を採用したが、実際のギャップ間隔 は取付け精度が設置場所ごとに異なるため、対応精度を向上させる にはより細かな設定が必要である。

建屋の応答值は柱、梁、ブレース共いずれも塑性率 0.3 以下であ り、解析結果から見て振動レベルは弾性範囲内である。また、ねじ れの影響については 8 階の同一平面内の 2 点の波形を比較した結果、 観測記録と同様の傾向を示し、その影響は小さいと考えられる。

非線形解析と線形解析の比較からはサイスミックタイの接触によ りピークが短周期側に移動し、ピーク值が減少する傾向が見られる。

最大值を含む主要動部分 10 秒間の加速度波形を観測記録と解析 結果で比較して図 15 に示す。2 地震共建屋側、ボイラ側共に良く 再現できている。芸予地震では 6 階ボイラ側に短周期の大きなパル ス波形が発生しているが、これは建屋とボイラの接触に伴うボイラ 函体の局部的な振動によるものであると考えられ、解析では表現で きていない。 $10 \mathrm{~Hz}$ 以上の短周期成分をフィルタし、この影響を除 いた波形と解析結果は比較的良く対応する。
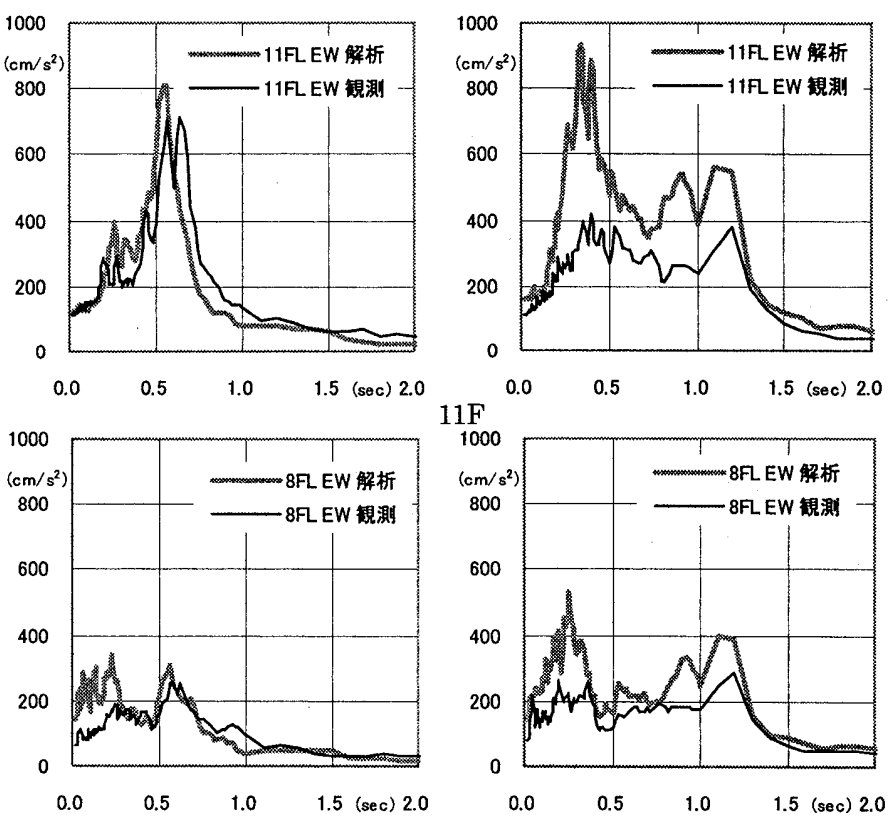
$8 \mathrm{~F}$

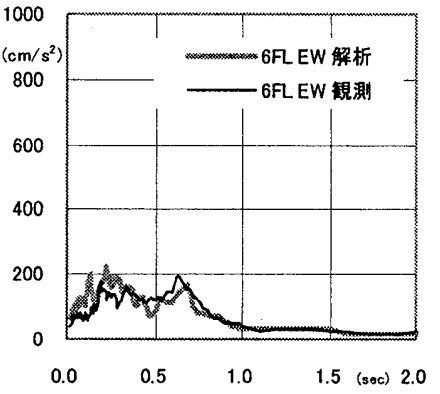

鳥取県西部地震 $E W(h=3 \%) 6$

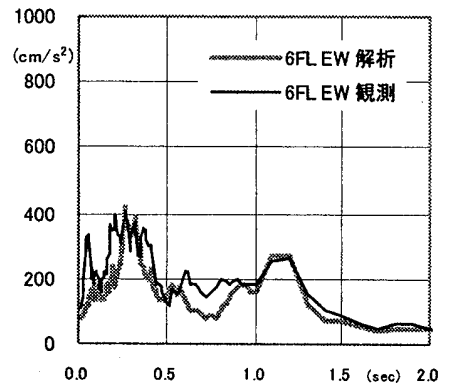

芸予地震 $\mathrm{EW}(\mathrm{h}=3 \%)$

図 14 観測記録と解析結果の加速度応答スペクトルの比較 

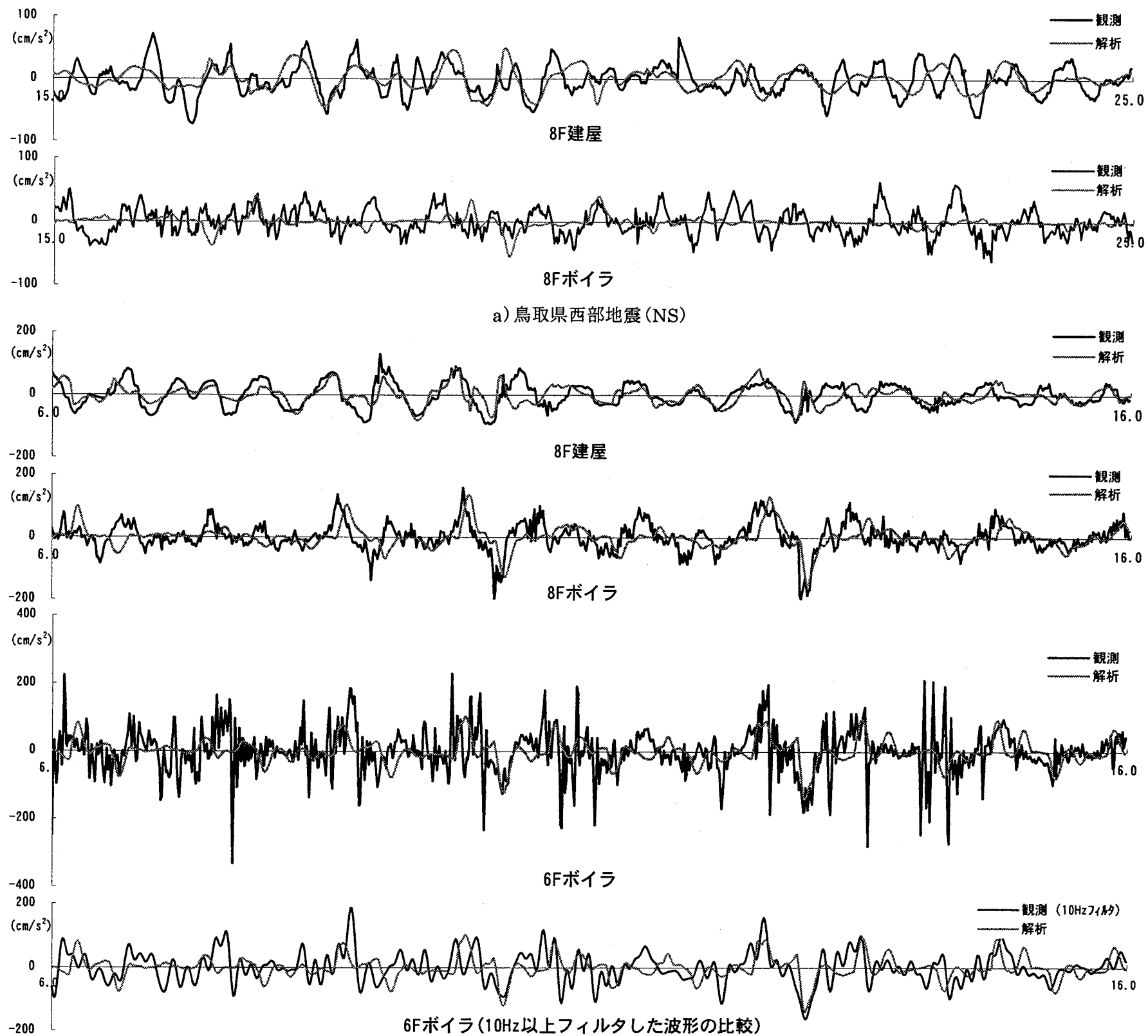

b）芸予地震（NS）

図 15 観測記録と解析結果の加速度波形比較

\section{5. まとめ}

竹原火力発電所 3 号機ボイラ建屋において観測された鳥取県西部 地震および芸予地震の記録のシミュレーション解析を行った。その 結果以下のことが判明した。

1） 2 地震の入カレベルは $30 \sim 50 \mathrm{~cm} / \mathrm{s}^{2}$ であり、建屋の応答は弾性 範囲にある。建屋とボイラはサイスミックタイを介して接触し ている状況である。

2）観測記録に見られる建屋の卓越周期はN S、EW方向共に 0.6 秒付近にある。建屋ボイラ非連成時の固有周期より短めである が、解析結果の卓越周期とはほぼ対応している。

3 ）設計時の建屋の剛性、重量を用いたフレーム㦿ばね連結の擬似

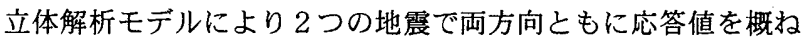
シミュレーションすることが可能である。
4) サイスミックタイのギャップ間隔が建物全体の応答性状に与え る影響は大きく、設計においては適切な評価が重要である。

\section{参考文献}

1) 加藤正治、三浦俊悦、山田和彦、前田達哉他 5 名: 火力発電所ボイ

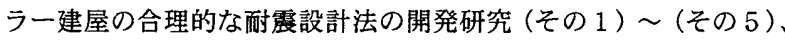
日本建築学会大会学術講演梗概集 p.1047 1056、1986.8

2）加藤正治、三浦俊悦他 1 名：火力発電所ボイラー棟の地震応答に関 する研究（その1）～(その 2 )、日本建築学会大会学術講演梗 概集、p.983 986、1984.10

3 ) M.D.Trifunac :Low Frequency Digitization Errors and a New Method for Zero Baseline Correction of Strong-Motion Accelerograms、EERL 70-07、1970.9

[2002年10月18日原稿受理２003年 2 月25日採用決定］ 